\title{
Serum levels of IL-6, IL-10 and TNF- $\alpha$ in patients with bipolar disorder and schizophrenia: differences in pro- and anti-inflammatory balance
}

\author{
Níveis séricos de IL-6, IL-10 e TNF- $\alpha$ em pacientes com transtorno \\ bipolar e esquizofrenia: diferenças no equilíbrio pró e \\ antiinflamatório
}

\author{
Mauricio Kunz, ${ }^{1,2,3,4}$ Keila Maria Ceresér, ${ }^{1,2,3,4}$ Pedro Domingues Goi, ${ }^{1,2,3,4}$ Gabriel Rodrigo Fries, ${ }^{1,2,3,5}$ Antonio \\ L. Teixeira, ${ }^{6}$ Brisa Simões Fernandes, ${ }^{1,2,3,4}$ Paulo Silva Belmonte-de-Abreu, ${ }^{3,4,7}$ Márcia Kauer-Sant'Anna, ${ }^{1,2,3,4}$ \\ Flavio Kapczinski, 1,2,3,4 Clarissa Severino Gama1,2,3,4,7

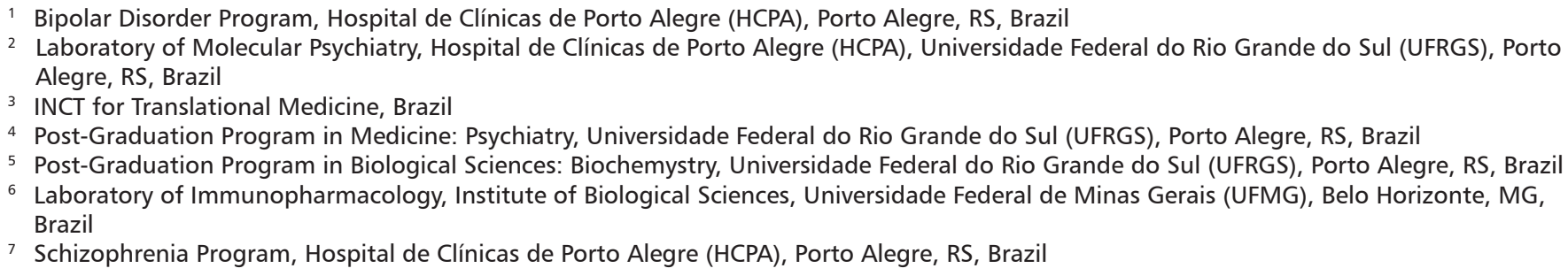

\begin{abstract}
Objective: Previous reports suggest that cytokines act as potential mediators of the interaction between the immune and neuroendocrine systems, and that a proinflammatory state may be associated with bipolar disorder and schizophrenia. The aim is to compare cytokine levels in both disorders. Method: Twenty euthymic bipolar disorder patients, 53 chronic stabilized schizophrenia patients and 80 healthy controls were recruited. Subjects were all non-smokers and non-obese. Cytokines TNF- $\alpha$, IL-6, and IL-10 were examined by sandwich ELISA. Results: IL-6 levels were increased in schizophrenia patients when compared to controls $(\mathrm{p}<0.0001)$ and euthymic bipolar disorder patients ( $\mathrm{p}<0.0001$ ). IL-6 levels were no different in controls compared to euthymic bipolar disorder patients $(\mathrm{p}=0.357)$. IL-10 was lower in controls compared to schizophrenia patients $(\mathrm{p}=0.001)$ or to bipolar disorder patients $(\mathrm{p}=0.004)$. There was no significant difference in TNF- $\alpha$ serum levels among the groups $(\mathrm{p}=0.284)$. Gender-based classification did not significantly alter these findings, and no correlation was found between the antipsychotic dose administered and cytokine levels in patients with schizophrenia. Discussion: These findings evidence a chronic immune activation in schizophrenia. Bipolar disorder seems to present an episode-related inflammatory syndrome. Increased anti-inflammatory factor IL-10 in bipolar disorder and schizophrenia suggests different patterns of inflammatory balance between these two disorders. Results further support the need to investigate cytokines as possible biomarkers of disease activity or treatment response.
\end{abstract}

Descriptors: Bipolar disorder; Schizophrenia; Interleukin-6; Interleukin-10; Tumor necrosis factor-alpha

\section{Resumo}

Objetivo: Pesquisas sugerem as citocinas como potenciais mediadores da interação entre os sistemas imune e neuroendócrino, e que existe um estado pró-inflamatório associado com transtorno bipolar e esquizofrenia. O objetivo deste estudo é comparar os niveis de citocinas entre os dois distúrbios. Método: Vinte pacientes com transtorno bipolar eutímicos, 53 pacientes com esquizofrenia crônica estabilizados e 80 controles saudáveis foram recrutados. Todos os individuos eram não-fumantes e não-obesos. As citocinas TNF- $\alpha$, IL-6 e IL-10 foram examinadas por ELISA sanduiche. Resultados: A IL-6 estava aumentada nos pacientes com esquizofrenia quando comparados aos controles $(p<0,0001)$ e aos pacientes bipolares eutímicos $(p<0,0001)$. Os niveis de IL-6 não foram diferentes nos controles em comparação com pacientes com transtorno bipolar eutímicos ( $p=0,357)$. Os niveis de IL-10 foram menores nos controles quando comparados aos pacientes com esquizofrenia $(p=0,001)$ ou aos bipolares $(p=0,004)$. Não houve diferença significativa nos niveis séricos de TNF- $\alpha$ entre os grupos $(p=0,284)$. A separação por sexo não mostrou diferenças significativas e não houve correlação entre a dose de antipsicóticos e os niveis de citocinas em pacientes com esquizofrenia. Discussão: Estes resultados evidenciam uma ativação imune crônica na esquizofrenia. O transtorno bipolar parece apresentar um aumento da atividade inflamatória relacionado ao episódio de humor. Niveis maiores de IL-10 no transtorno bipolar e esquizofrenia sugerem diferentes padröes de equilibrio inflamatório entre esses dois transtornos. Resultados fornecem apoio adicional para a investigação de citocinas como possiveis biomarcadores para a atividade da doença ou resposta ao tratamento.

Descritores: Transtorno bipolar; Esquizofrenia; Interleucina-6; Interleucina-10; Fator de necrose tumoral alfa
Submitted: June 7, 2010

Accepted: July 22, 2010

\section{Correspondence}

Clarissa Severino Gama

Hospital de Clínicas de Porto Alegre -

Molecular Psychiatry Laboratory

Rua Ramiro Barcelos, 2350 - Prédio Anexo

90035-903 Porto Alegre, RS, Brasil

Phone: (+55 51) 3359-8845 FAX: (+55 51) 3359-8846

E-mail:csgama@yahoo.com 


\section{Introduction}

Bipolar disorder and schizophrenia share many epidemiologic and clinical features. ${ }^{1}$ Increasing data suggest an overlap in genetic susceptibility across the two diagnoses. ${ }^{2}$ Although their pathophysiology remains unclear, mechanisms such as oxidative stress and neuroplasticity have recently been implicated..$^{3-6}$ However, these mechanisms seem to be differently involved in each disorder. ${ }^{7,8}$

It is well known that people with severe mental illnesses such as schizophrenia (SZ) or bipolar disorder (BD) have worse physical health outcomes and reduced life expectancy compared to the general population. ${ }^{9}$ The excessive cardiovascular mortality associated with $\mathrm{SZ}$ and $\mathrm{BD}$ is attributed in part to an increased risk of the modifiable atherosclerotic risk factors: obesity, smoking, diabetes, hypertension and dyslipidaemia. ${ }^{10-12}$ Inflammation is a mechanism that plays a part not only in atherosclerosis but also in different neuropsychiatric disorders, where it is involved in complex and reciprocal interactions with neurotrophins and oxidative stress. Considering these interactions, a Systemic Toxicity Index for mood episodes has recently been proposed to study neurotrophins, oxidative stress markers and inflammatory markers. ${ }^{13}$

The action of cytokines on brain cells has been shown to be an important component of the neuroimmunological and neuroinflammatory response. Cytokines and related secretory products from immune cells communicate with the endocrine and central nervous system to modulate their collective functions. ${ }^{14}$ In the field of mood disorders, the immune system seems to play a particularly important role. Over the years, a significant body of accumulated evidence suggests that major depression is associated with dysfunction of inflammatory mediators. ${ }^{15}$ Patients with unipolar depression who are otherwise clinically healthy have been shown to present activated inflammatory pathways, with increased pro-inflammatory cytokines, acute-phase proteins, and increased expression of chemokines and adhesion molecules. ${ }^{16-18}$

More recently, available evidence indicates that $\mathrm{BD}$ and inflammation are linked through shared genetic polymorphisms and gene expression, as well as altered cytokine levels ${ }^{19}$ during acute episodes ${ }^{20}$ and euthymia. ${ }^{21}$ It has been suggested that inflammatory cytokines, particularly TNF- $\alpha$, may play a critical role in changes in neuroplasticity, cell resilience and neuronal survival. ${ }^{22,23}$ Additionally, the combination of brain-derived neurotrophic factor (BDNF) and TNF- $\alpha$ serum levels has been proposed as staging biomarkers for $\mathrm{BD} .^{24}$

Inflammatory processes have also been implicated in the pathophysiology of SZ, and different studies have focused on the role of inflammation in SZ. ${ }^{25}$ Many observations of immune deregulation in SZ overlap with central pathophysiological mechanisms as well as with clinical manifestations of the illness. This is supported by a growing database of investigations, some of which even suggest that a subgroup of patients with SZ present the features of an autoimmune process. ${ }^{26}$ Although this is a concept that has not yet been fully grasped, the general evidence of the existence of a pro-inflammatory state in SZ is, indeed, consistent. ${ }^{23}$
So far, no other study has compared the levels of inflammatory markers present in BD and SZ. The examination of the different expression of physiopathological mechanisms may provide a better understanding of the etiological processes underlying both disorders, as well as new possibilities for treatment. Therefore, this study was designed to examine both euthymic patients with $\mathrm{BD}$ and chronic stabilized patients with SZ by comparing their cytokine levels against those from healthy controls.

\section{Method \\ 1. Subjects}

This study protocol was approved by the ethics committee of the Hospital de Clínicas de Porto Alegre (HCPA), in Rio Grande do Sul, Brazil. All subjects provided their written informed consent before inclusion in the study.

We selected 53 chronically medicated and stabilized outpatients with SZ from the HCPA Schizophrenia Program, and 20 euthymic outpatients with BD from the HCPA Bipolar Disorders Program. All subjects were clinically interviewed by a trained psychiatrist. Only those patients and controls who were non-smokers and non-obese, and who did not present any major medical condition, such as atherosclerotic heart disease or diabetes, were included in the study. Obesity was defined as a body mass index (weight in kilograms/height ${ }^{2}$ in meters) of 30 or higher. The diagnosis of BD and SZ were confirmed according to the Diagnostic and Statistical Manual of Mental Disorders, fourth Edition (DSM-IV). ${ }^{27}$ The psychiatric status of patients with SZ was assessed using the Brief Psychiatric Rating Scale (BPRS) ${ }^{28}$ and the Clinical Global Impression (CGI). ${ }^{29}$ Only patients with BPRS scores $\leq 25$ and no history of a psychiatric hospitalization over the last two years were included in the study. Mood symptoms in patients with BD were identified using the Young Mania Rating Scale (YMRS) ${ }^{30}$ and the Hamilton Depression Rating Scale (HAMD-21). ${ }^{31}$ Patients were considered euthymic and, therefore, able to participate in the study if both the YMRS and the HAMD scores were lower than seven. The control group consisted of 80 medication-free healthy volunteers who had no current or previous history, as well as no first-degree family member with a history of a major psychiatric disorder, including dementia or mental retardation as evaluated by the non-patient version of the Structured Clinical Interview for DSM-IV (SCID).

\section{Serum cytokines measurement}

Five milliliters of anticoagulant-free blood were drawn by venipuncture from each subject on the day of clinical interview. Serum was obtained by centrifugation at 3,000xg for 5 minutes and then kept frozen at $-70^{\circ} \mathrm{C}$ until the assay i.e., six months later.

Serum cytokines were measured as instructed by the manufacturer, using sandwich ELISA kits for TNF- $\alpha$, IL-6 and IL-10 (DuoSet, R\&D Systems, Minneapolis, Minn., USA). All samples were assayed in duplicates and the same plate was used. Detection limits for these assays were set at $5 \mathrm{pg} / \mathrm{ml}$. In brief, the capture antibody (concentration provided by the manufacturer) was diluted in PBS, added to each well and left overnight at $4^{\circ} \mathrm{C}$. 
The plate was washed 4 times in PBS with $0.05 \%$ Tween-20 (Sigma, St. Louis, Mo., USA). The plate was blocked with $1 \%$ bovine serum albumin and incubated for 1 hour at room temperature before being washed four times with PBS and 0.05\% Tween-20. The samples and standards were added, and the plate incubated overnight at $4^{\circ} \mathrm{C}$. After the plate had been washed, detection antibody (concentration provided by the manufacturer) diluted in PBS was added. The plate was incubated for 2 hours at room temperature. After the plate had been washed, streptavidin (DuoSet, R\&D Systems) was added and the plate incubated for 30 minutes. Finally, color reagent o-phenylenediamine (Sigma) was added to each well, and the reaction was allowed to develop in the dark for 15 minutes. The reaction was interrupted for the addition of $1 \mathrm{M} \mathrm{H} 2 \mathrm{SO} 4$ to each well. The absorbance was read on a plate reader at $492 \mathrm{~nm}$ (Emax, Molecular Devices, Minneapolis, Minn., USA).

\section{Statistical analysis}

As indicated, demographic and clinical characteristics were analyzed using chi-square and ANOVA tests. Descriptive analyses are presented as mean (standard deviation, SD) or median (interquartile range), and p-values $<0.05$ were considered significant. Cytokine levels showed a non-Gaussian distribution and were analyzed by applying the appropriate tests: the KruskalWallis test and the Mann-Whitney test. Relationships between variables were assessed with Spearman rank correlation coefficient. Analysis was performed using SPSS Version 16.0.

\section{Results}

The subjects' demographics and clinical characteristics are summarized in Table 1 . The three groups were not significantly different in terms of age $(p=0.115)$. Length of illness was longer in the group with $\mathrm{SZ}$ than in the group with $\mathrm{BD}$ (18.0, $\mathrm{SD}=16.7$ vs. $12.0, \mathrm{SD}=16.3, \mathrm{p}=0.026)$. Patients with $S Z$ were predominantly male $(76 \%)$, while the $\mathrm{BD}$ and control groups had a lower frequency of male subjects ( $40 \%$ in both groups). In the SZ group, 12 patients were on atypical antipsychotics, 13 on typical antipsychotics and 28 on clozapine. The BD group had 15 patients on lithium, 8 on other mood stabilizers, 10 on antipsychotics, 3 on antidepressants and 6 on benzodiazepines.

IL-6 was significantly increased in patients with SZ when compared to either the controls $(p<0.0001)$ or the euthymic patients with BD ( $\mathrm{p}<0.0001)$. IL-6 levels were no different in controls compared to euthymic BD patients ( $\mathrm{p}=0.357)$. IL-10 was significantly lower in controls compared to $S Z(p=0.001)$ or BD ( $\mathrm{p}=0.004)$. There was no significant difference in TNF- $\alpha$ serum levels among the three groups $(\mathrm{p}=0.284)$ - Figure 1 . The significance did not change when patients were classified by gender $(\mathrm{p}<0.001$ and $\mathrm{p}=0.008$ for IL-6, $\mathrm{p}=0.003$ and $\mathrm{p}=0.048$ for IL10 and $p=0.165$ and $p=0.159$ for TNF- $\alpha$, for males and females, respectively). In patients with $S Z$, no correlation was found between the antipsychotic dose (in milligrams of chlorpromazine equivalents) and IL-6 (rho $=-0.267, \mathrm{p}=0.084$ ), IL-10 $($ rho $=0.031, \mathrm{p}=0.845)$ or TNF- $\alpha($ rho $=-0.145, \mathrm{p}=0.363)$.

\section{Discussion}

Our results are in line with those from previous reports on the presence of increased inflammatory markers in BD and SZ. However, we found significantly higher levels of pro-inflammatory cytokine IL-6 in patients with SZ compared to either patients with $\mathrm{BD}$ or healthy controls. Previous reports have found an association with IL-6 and acute symptomatology in $\mathrm{BD}^{20}$ and SZ. ${ }^{32}$ Considering that our comparison involved patients in non-acute phases of illness (euthymic BD vs. chronic SZ), our finding that there is an increased presence of IL-6 in SZ provides further evidence of a chronic immune activation and inflammatory syndrome in SZ. ${ }^{23}$ While increased IL-6 seems to be state-dependent in $\mathrm{BD}$, it seems to be a trait in patients with $\mathrm{SZ}$. Nevertheless, this finding could also be explained by the longer duration of the illness in the SZ group. ${ }^{33}$

Increased levels of TNF- $\alpha$ have also been previously reported

Table 1 - Characteristics of healthy controls and patients with bipolar disorder (BD) and schizophrenia (SZ)

\begin{tabular}{|c|c|c|c|c|}
\hline & $\begin{array}{c}S Z \\
(n=53)\end{array}$ & $\begin{array}{l}\text { BD euthymic } \\
\qquad(n=20)\end{array}$ & $\begin{array}{l}\text { Control group } \\
\qquad(n=80)\end{array}$ & p-value \\
\hline Gender (M/F proportion) & $75.5 / 24.5$ & $40 / 60$ & $40 / 60$ & $<0.0001^{*}$ \\
\hline Years of illness ${ }^{\dagger \dagger}$ & $18.0(16.7)$ & $12.0(16.3)$ & - & $0.026^{\star \star \star}$ \\
\hline YMRS score & - & $1.5(6.5)$ & - & - \\
\hline HAMD score ${ }^{\dagger \dagger}$ & - & $4.0(4.5)$ & - & - \\
\hline CGI score ${ }^{t \dagger}$ & $2.0(1.0)$ & - & - & - \\
\hline $\begin{array}{l}\text { Antipsychotic daily dose, in } \mathrm{mg} \text { of } \\
\text { chlorpromazine equivalents }^{\dagger}\end{array}$ & $501.9(218.1)$ & - & - & - \\
\hline
\end{tabular}

YMRS: Young Mania Rating Scale; HAMD: Hamilton Depression Rating Scale; BPRS: Brief Psychiatry Rating Scale; CGI: Clinical Global Impression. * Chi-Square. ${ }^{* *}$ One-way ANOVA. ${ }^{* * *}$ Mann-Whitney. ${ }^{\dagger}$ Shown as mean \pm standard deviation. ${ }^{+\dagger}$ Shown as median (interquartile range).

Control/euthymic vs. SZ, $p<0.0001$ (Mann-Whitney)

SZleuthymic vs. control, $p=0.004$ (Mann-Whitney) 
A

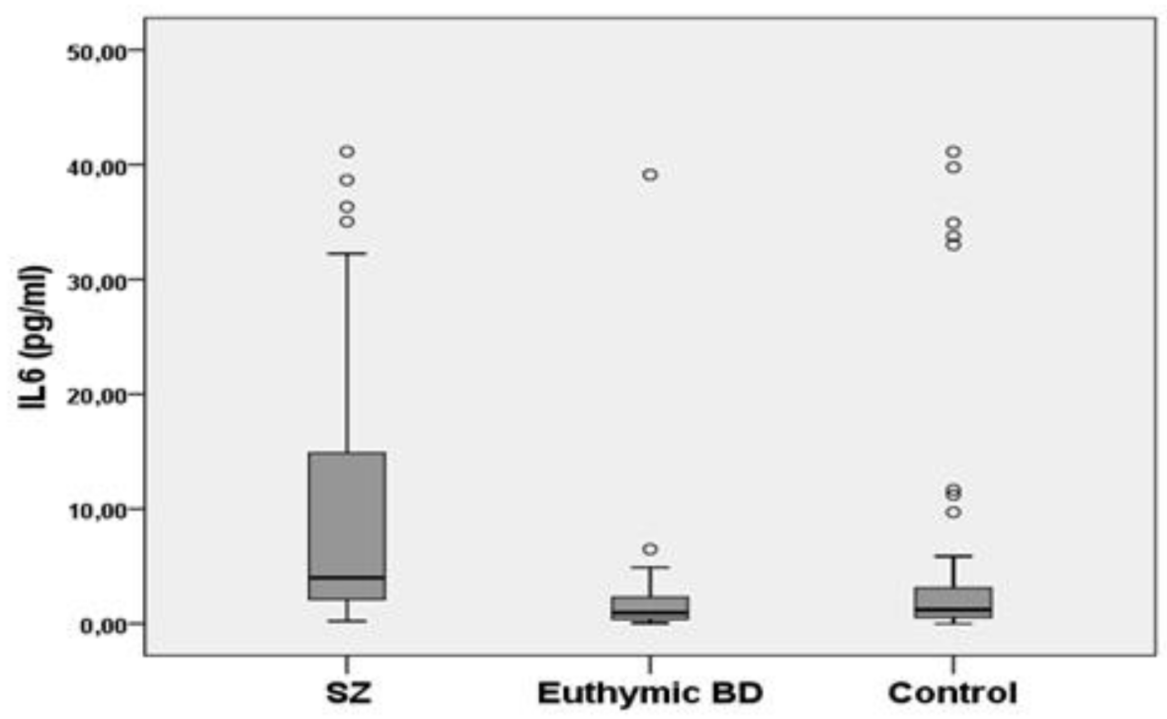

B

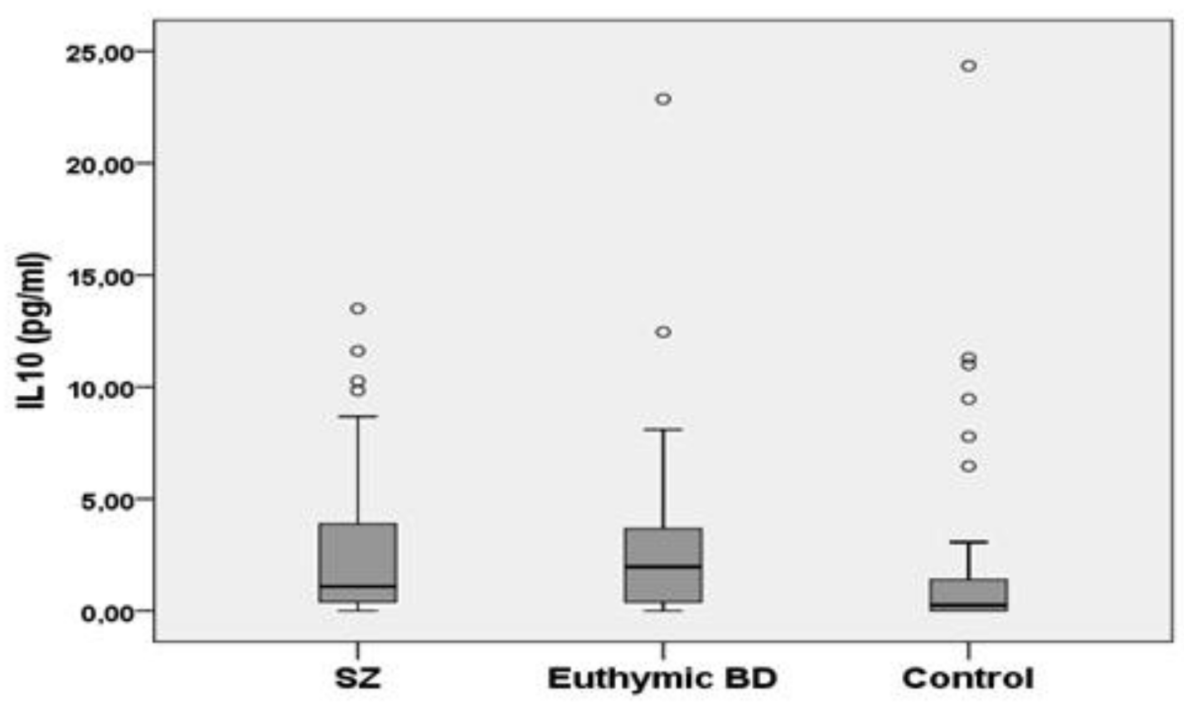

C

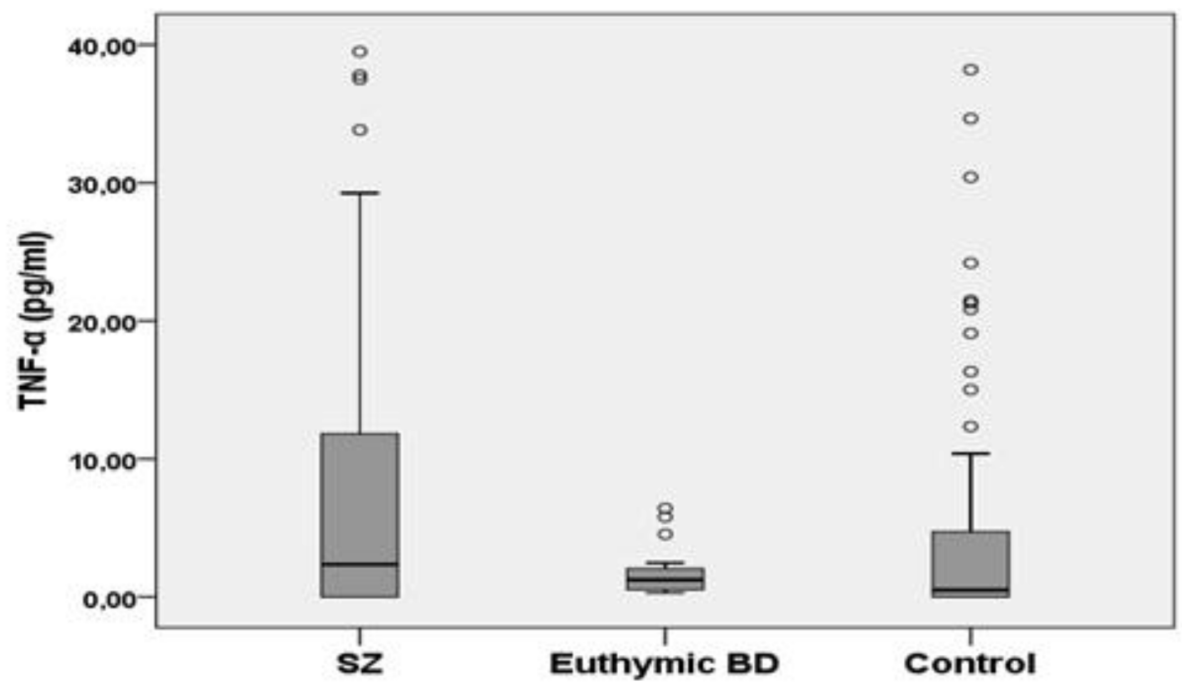

Figure 1 - A) Box-plot of serum IL6 levels in SZ patients, BD euthymic and controls. Median levels are indicated by horizontal lines, outliers are indicated by $O$. Kruskal-Wallis test was performed to analyze variance between groups $(p<0.0001)$ and multiple comparisons were assessed by Mann-Whitney test (control vs. SZ, $p<0.0001$; euthymic vs. SZ, $p<0.0001$ ). B) Box-plot of serum IL10 levels in SZ patients, BD euthymic and controls. Median levels are indicated by horizontal lines, outliers are indicated by $\mathrm{O}$ or *. Kruskal-Wallis test was performed to analyze variance between groups $(p=0.001)$ and multiple comparisons were assessed by Mann-Whitney test (euthymic vs. control, $p=0.004 ; S Z$ vs. Control, $p=0.001$ ). C) Box-plot of serum TNF-a levels in SZ patients, BD euthymic and controls. Median levels are indicated by horizontal lines, outliers are indicated by $\mathrm{O}$ or ${ }^{*}$. Kruskal-Wallis test was performed to analyze variance between groups $(p=0.284)$. 
in BD and SZ, and have been shown to be associated with the symptomatology of both disorders. ${ }^{20,34}$ Therefore, the fact that TNF- $\alpha$ levels were not different from those of the controls in our sample can be explained by the non-acute profile of our subjects.

Even though inflammation plays a role in both disorders, the overall balance of pro- and anti-inflammatory components is differently expressed. With this in mind, the increased levels of anti-inflammatory IL-10 found in both the SZ and BD groups, when compared to controls, should not be easily dismissed. While this could be attributed to a direct response to the elevation of IL-6 in SZ, this phenomenon could also reflect a compensatory mechanism derived from previous episodes in BD. As levels of IL-10 seem to decline with the progression of the disease, ${ }^{35}$ the general pro-inflammatory balance in $\mathrm{BD}$ worsens in the later stages of the illness as the anti-inflammatory response abates.

We believe that a comparative assessment of the pathophysiological mechanisms at play in $\mathrm{BD}$ and $\mathrm{SZ}$ may provide interesting insights into the different roles played by such mechanisms in each disorder. Past comparisons have suggested that different profiles of oxidative stress, ${ }^{8}$ neurotrophins ${ }^{7}$ and different patterns of correlation between oxidative stress markers and neurotrophins are at play in $\mathrm{SZ}^{36}$ and BD. ${ }^{37}$ While different lines of evidence suggest that, in $\mathrm{BD}$, we can see an episode-related deterioration pattern, it appears that, in SZ, this deterioration pattern seems to be of a chronic nature, starting at the onset of the illness. This observation brings us back to the classic differentiation between the two diagnoses based on either an episodic or a chronic-deteriorating course. In SZ, however, difficulties in defining remission in a chronically ill and stable population may not allow for a clear differentiation of state and trait effects.

The interpretation of this report and its results must take into consideration certain limitations, which include a lack of control for potential confounders. Factors such as diet and level of physical activity can substantially contribute to alterations in inflammatory markers. ${ }^{11,38,39}$ The excessive incidence of medical conditions in both $\mathrm{BD}$ and $\mathrm{SZ}$ is increasingly recognized. ${ }^{9}$ The majority of these conditions are related to inflammation, especially cardiovascular illness, obesity and insulin resistance. Even though patients with significant medical problems were excluded from our study, controlling for medical conditions, metabolic alterations and lifestyle factors was not possible.

Another potential confounder is related to the different medications used by patients with BP and SZ. It appears that mood stabilizers in general (and lithium more specifically) attenuate the pro-inflammatory milieu in BD. ${ }^{19}$ Similarly, antipsychotics may also impact the production of cytokines. ${ }^{40}$ Therefore, even in the absence of any correlation between cytokine levels and the dose of antipsychotic medications taken by our subjects, the confounder effect of medications cannot be ruled out.

Our findings point to the involvement of inflammatory mechanisms as a component of the pathophysiology of both $\mathrm{BD}$ and SZ, and provide insight into the different patterns seen in this association. We believe that studies aimed at performing a comparative analysis among disorders may provide a more thorough understanding of the inflammatory component at play in psychiatric illnesses, thus providing a basis for improved forms of intervention.

\section{Acknowledgements}

Clarissa Severino Gama is funded by research grants from $\mathrm{CNPq}$ (Universal 477974/2009-0 and PQ 305967/2008-8), Brazil. 
Disclosures

\begin{tabular}{|c|c|c|c|c|c|c|c|}
\hline $\begin{array}{l}\text { Writing } \\
\text { group } \\
\text { member }\end{array}$ & Employment & $\begin{array}{l}\text { Research } \\
\text { grant }^{1}\end{array}$ & $\begin{array}{l}\text { Other research } \\
\text { grant or medical } \\
\text { continuous } \\
\text { education }^{2}\end{array}$ & $\begin{array}{l}\text { Speaker's } \\
\text { honoraria }\end{array}$ & $\begin{array}{c}\text { Ownership } \\
\text { interest }\end{array}$ & $\begin{array}{l}\text { Consultant/ } \\
\text { Advisory } \\
\text { board }\end{array}$ & Other $^{3}$ \\
\hline $\begin{array}{l}\text { Mauricio } \\
\text { Kunz }\end{array}$ & HCPA/UFRGS & $\mathrm{CNPq}^{* *}$ & - & - & - & - & - \\
\hline $\begin{array}{l}\text { Keila Maria } \\
\text { Ceresér }\end{array}$ & HCPA/UFRGS & CAPES** & - & - & - & - & - \\
\hline $\begin{array}{l}\text { Pedro } \\
\text { Domingues } \\
\text { Goi }\end{array}$ & HCPA/UFRGS & CAPES** & - & - & - & - & - \\
\hline $\begin{array}{l}\text { Gabriel } \\
\text { Rodrigo Fries }\end{array}$ & HCPA/UFRGS & - & - & - & - & - & - \\
\hline $\begin{array}{l}\text { Antonio L. } \\
\text { Teixeira }\end{array}$ & UFMG & - & - & - & - & - & - \\
\hline $\begin{array}{l}\text { Brisa Simões } \\
\text { Fernandes }\end{array}$ & UFRGS & - & - & - & - & - & - \\
\hline $\begin{array}{l}\text { Paulo Silva } \\
\text { Belmonte-de- } \\
\text { Abreu }\end{array}$ & HCPA/UFRGS & $\begin{array}{l}\text { CAPES- } \\
\text { GRICES*** } \\
\text { CNPq }^{* * *} \\
\end{array}$ & - & - & - & - & - \\
\hline $\begin{array}{l}\text { Márcia Kauer- } \\
\text { Sant'Anna }\end{array}$ & HCPA/UFRGS & $\begin{array}{c}\text { FIPE-HCPA }^{*} \\
\text { CNPq }^{* *} \\
\text { CNPq }^{* * *} \\
\text { Stanley } \\
\text { NARSAD** } \\
\text { CAPES }^{* * *}\end{array}$ & - & $\begin{array}{l}\text { AstraZeneca* } \\
\text { Eli-Lilly* }\end{array}$ & - & - & - \\
\hline $\begin{array}{l}\text { Flavio } \\
\text { Kapczinski }\end{array}$ & HCPA/UFRGS & $\begin{array}{c}\text { AstraZeneca }^{* *} \\
\text { Eli-Lilly**} \\
\text { Janssen- }^{* *} \text { Cilag }^{\star *} \\
\text { Servier**} \\
\text { FIPE-HCPA } \\
\text { CNPq }^{* *} \\
\text { Stanley }^{* \star *} \\
\text { NARSAD }^{* *} \\
\text { CAPES } \\
\end{array}$ & - & $\begin{array}{l}\text { AstraZeneca }^{* *} \\
\text { Eli-Lilly**} \\
\text { Janssen-Cilag** } \\
\text { Servier** }\end{array}$ & - & Servier & - \\
\hline $\begin{array}{l}\text { Clarissa } \\
\text { Severino } \\
\text { Gama }\end{array}$ & HCPA/UFRGS & $\begin{array}{c}\text { FIPE-HCPA }^{*} \\
\text { CNPq }^{* *} \\
\text { CNPq }^{* * *} \\
\text { Stanley }^{* * * *} \\
\text { NARSAD } \\
\text { CAPES- } \\
\text { GRICES } \\
\text { G** }\end{array}$ & - & $\begin{array}{l}\text { AstraZeneca* } \\
\text { Lundbeck* }^{*} \\
\text { Actelion } \\
\text { Pharmaceutical } \\
\text { Ltd.* }^{*}\end{array}$ & - & $\begin{array}{c}\text { Actelion } \\
\text { Pharmaceutical } \\
\text { Ltd. }{ }^{*}\end{array}$ & $\begin{array}{l}\text { AstraZeneca } \\
\text { Elli Lilly } \\
\text { Jansen-Cilag }\end{array}$ \\
\hline
\end{tabular}

${ }^{*}$ Modest

** Significant

*** Significant: Amounts given to the author's institution or to a colleague for research in which the author has participation, not directly to the author.

Note: HCPA = Hospital de Cllinicas de Porto Alegre; UFRGS = Universidade Federal do Rio grande do Sul; UFMG = Universidade Federal de Minas Gerais; $C N P q=$ Conselho nacional de Desenvolvimento Científico e Tecnológico; CAPES = Coordenação de Aperfeiçoamento de Pessoal de Nivel Superior; FIPE = Fundo de Incentivo à Pesquisa e Eventos; NARSAD = National Alliance for Research on Schizophrenia and Depression.

For more information, see Instructions for Authors.

\section{References}

1. Berrettini WH. Are schizophrenic and bipolar disorders related? A review of family and molecular studies. Biol Psychiatry. 2000;48(6):531-8.

2. Craddock N, O'Donovan MC, Owen MJ. Genes for schizophrenia and bipolar disorder? Implications for psychiatric nosology. Schizophr Bull. 2006;32(1):9-16. 3. Andreazza AC, Kauer-Sant’anna M, Frey BN, Bond DJ, Kapczinski F, Young LT, Yatham LN. Oxidative stress markers in bipolar disorder: a meta-analysis. $J$ Affect Disord. 2008;111(2-3):135-44.
4. Gama CS, Salvador M, Andreazza AC, Kapczinski F, Silva Belmonte-deAbreu P. Elevated serum superoxide dismutase and thiobarbituric acid reactive substances in schizophrenia: a study of patients treated with haloperidol or clozapine. Prog Neuropsychopharmacol Biol Psychiatry. 2006;30(3):512-5.

5. Gama CS, Salvador M, Andreazza AC, Lobato MI, Berk M, Kapczinski F, Belmonte-de-Abreu PS. Elevated serum thiobarbituric acid reactive substances in clinically symptomatic schizophrenic males. Neurosci Lett. 2008;433(3):270-3 
6. Vargas HE, Gama CS, Andreazza AC, Medeiros D, Stertz L, Fries G, Palha J, Cereser KM, Berk M, Kapczinski F, Belmonte-de-Abreu PS. Decreased serum neurotrophin 3 in chronically medicated schizophrenic males. Neurosci Lett. 2008;440(3):197-201.

7. Gama CS, Andreazza AC, Kunz M, Berk M, Belmonte-de-Abreu PS, Kapczinski F. Serum levels of brain-derived neurotrophic factor in patients with schizophrenia and bipolar disorder. Neurosci Lett. 2007;420(1):45-8.

8. Kunz M, Gama CS, Andreazza AC, Salvador M, Cereser KM, Gomes FA, Belmonte-de-Abreu PS, Berk M, Kapczinski F. Elevated serum superoxide dismutase and thiobarbituric acid reactive substances in different phases of bipolar disorder and in schizophrenia. Prog Neuropsychopharmacol Biol Psychiatry. 2008;32(7):1677-81.

9. Roshanaei-Moghaddam B, Katon W. Premature mortality from general medical illnesses among persons with bipolar disorder: a review. Psychiatr Serv. 2009;60(2):147-56.

10. Elkis H, Gama C, Suplicy H, Tambascia M, Bressan R, Lyra R, Cavalcante S, Minicucci W. Brazilian Consensus on second-generation antipsychotics and metabolic disorders. Rev Bras Psiquiatr. 2008;30(1):77-85.

11. Guimaraes LR, Jacka FN, Gama CS, Berk M, Leitao-Azevedo CL, Belmonte de Abreu MG, Lobato MI, Andreazza AC, Cereser KM, Kapczinski F, Belmontede-Abreu P. Serum levels of brain-derived neurotrophic factor in schizophrenia on a hypocaloric diet. Prog Neuropsychopharmacol Biol Psychiatry. 2008;32(6):1595-8.

12. Leitao-Azevedo CL, Guimaraes LR, de Abreu MG, Gama CS, Lobato MI, Belmonte-de-Abreu PS. Increased dyslipidemia in schizophrenic outpatients using new generation antipsychotics. Rev Bras Psiquiatr. 2006;28(4):301-4.

13. Kapczinski F, Dal-Pizzol F, Teixeira AL, Magalhaes PV, Kauer-Sant'anna M, Klamt F, de Bittencourt Pasquali MA, Quevedo J, Gama CS, Post R. A systemic toxicity index developed to assess peripheral changes in mood episodes. Mol Psychiatry. 2010;15(8):784-6.

14. Turnbull AV, Rivier C. Regulation of the HPA axis by cytokines. Brain Behav Immun. 1995;9(4):253-75.

15. Licinio J, Wong ML. The role of inflammatory mediators in the biology of major depression: central nervous system cytokines modulate the biological substrate of depressive symptoms, regulate stress-responsive systems, and contribute to neurotoxicity and neuroprotection. Mol Psychiatry. 1999;4(4):317-27.

16. Kim YK, Na KS, Shin KH, Jung HY, Choi SH, Kim JB. Cytokine imbalance in the pathophysiology of major depressive disorder. Prog Neuropsychopharmacol Biol Psychiatry. 2007;31(5):1044-53.

17. Raison CL, Capuron L, Miller AH. Cytokines sing the blues: inflammation and the pathogenesis of depression. Trends Immunol. 2006;27(1):24-31.

18. Yang K, Xie G, Zhang Z, Wang C, Li W, Zhou W, Tang Y. Levels of serum interleukin (IL)-6, IL-1beta, tumour necrosis factor-alpha and leptin and their correlation in depression. Aust NZJ Psychiatry. 2007;41(3):266-73.

19. Goldstein BI, Kemp DE, Soczynska JK, McIntyre RS. Inflammation and the phenomenology, pathophysiology, comorbidity, and treatment of bipolar disorder: a systematic review of the literature. J Clin Psychiatry. 2009;70(8):1078-90.

20. Brietzke E, Stertz L, Fernandes BS, Kauer-Sant'anna M, Mascarenhas M, Escosteguy Vargas A, Chies JA, Kapczinski F. Comparison of cytokine levels in depressed, manic and euthymic patients with bipolar disorder. $J$ Affect Disord. 2009;116(3):214-7.

21. Brietzke E, Kauer-Sant'anna M, Teixeira AL, Kapczinski F. Abnormalities in serum chemokine levels in euthymic patients with bipolar disorder. Brain Behav Immun. 2009;23(8):1079-82.

22. Brietzke E, Kapczinski F. TNF-alpha as a molecular target in bipolar disorder. Prog Neuropsychopharmacol Biol Psychiatry. 2008;32(6):1355-61.

23. Potvin S, Stip E, Sepehry AA, Gendron A, Bah R, Kouassi E. Inflammatory cytokine alterations in schizophrenia: a systematic quantitative review. Biol Psychiatry. 2008;63(8):801-8.

24. Kapczinski F, Dias VV, Kauer-Sant'Anna M, Brietzke E, Vazquez GH, Vieta E, Berk M. The potential use of biomarkers as an adjunctive tool for staging bipolar disorder. Prog Neuropsychopharmacol Biol Psychiatry. 2009;33(8):1366-71. 25. Rothermundt M, Arolt V, Bayer TA. Review of immunological and immunopathological findings in schizophrenia. Brain Behav Immun. 2001;15(4):319-39.
26. Strous RD, Shoenfeld Y. Schizophrenia, autoimmunity and immune system dysregulation: a comprehensive model updated and revisited. J Autoimmun. 2006;27(2):71-80.

27. APA - American Psychiatry Association. Diagnostic and statistical manual of mental disorders. Washington, DC: American Psychiatry Association; 2000.

28. Romano F, Elkis H. Tradução e adaptação de um instrumento de avaliaçãa psicopatológica das psicoses: a escala breve de avaliação psiquiátrica. Versão Ancorada (BPRS-A). J Bras Psiquiatr. 1996;45:43-9.

29. Lima MS, Soares BG, Paoliello G, Machado Vieira R, Martins CM, Mota Neto JI, Ferrao Y, Schirmer DA, Volpe FM. The Portuguese version of the Clinical Global Impression-Schizophrenia Scale: validation study. Rev Bras Psiquiatr. 2007;29(3):246-9.

30. Young RC, Biggs JT, Ziegler VE, Meyer DA. A rating scale for mania: reliability, validity and sensitivity. Br J Psychiatry. 1978;133:429-35.

31. Hamilton M. A rating scale for depression. J Neurol Neurosurg Psychiatry. 1960;23:56-62.

32. Naudin J, Mege JL, Azorin JM, Dassa D. Elevated circulating levels of IL-6 in schizophrenia. Schizophr Res. 1996;20(3):269-73.

33. Ganguli R, Yang Z, Shurin G, Chengappa KN, Brar JS, Gubbi AV, Rabin BS. Serum interleukin- 6 concentration in schizophrenia: elevation associated with duration of illness. Psychiatry Res. 1994;51(1):1-10.

34. Erbagci AB, Herken H, Koyluoglu O, Yilmaz N, Tarakcioglu M. Serum IL1 beta, sIL-2R, IL-6, IL-8 and TNF-alpha in schizophrenic patients, relation with symptomatology and responsiveness to risperidone treatment. Mediators Inflamm. 2001;10(3):109-15

35. Kauer-Sant'Anna M, Kapczinski F, Andreazza AC, Bond DJ, Lam RW, Young LT, Yatham LN. Brain-derived neurotrophic factor and inflammatory markers in patients with early- vs. late-stage bipolar disorder. Int J Neuropsychopharmacol. 2009;12(4):447-58

36. Gama CS, Berk M, Andreazza AC, Kapczinski F, Belmonte-de-Abreu P. Serum levels of brain-derived neurotrophic factor and thiobarbituric acid reactive substances in chronically medicated schizophrenic patients: a positive correlation. Rev Bras Psiquiatr. 2008;30(4):337-40.

37. Kapczinski F, Frey BN, Andreazza AC, Kauer-Sant'Anna M, Cunha AB, Post RM. Increased oxidative stress as a mechanism for decreased BDNF levels in acute manic episodes. Rev Bras Psiquiatr. 2008;30(3):243-5.

38. Jacka FN, Gama CS, Berk M. Brain-derived neurotrophic factor: a modifiable common mediator in both the pathophysiology of psychiatric illness and in successful pharmacological treatments. Acta Neuropsychiatrica. 2008;20(4):223-5. 39. Molteni R, Barnard RJ, Ying Z, Roberts CK, Gomez-Pinilla F. A high-fat, refined sugar diet reduces hippocampal brain-derived neurotrophic factor, neuronal plasticity, and learning. Neuroscience. 2002;112(4):803-14.

40. Drzyzga L, Obuchowicz E, Marcinowska A, Herman ZS. Cytokines in schizophrenia and the effects of antipsychotic drugs. Brain Behav Immun. 2006;20(6):532-45. 